\title{
PHENOMENOGRAPHY ANALYSIS OF STUDENTS' HISTORICAL THINKING ABILITY IN STUDYING SOCIAL HISTORY
}

\author{
Agus Mulyana*, Yeni Kurniawati \\ University of Indonesia Education, Indonesia \\ *e-mail: agusmulyana66@upi.edu
}

\begin{abstract}
The Marton Phenomenography Analysis model is interesting to apply because it has a significant characteristic of learning that is based on two academic learning patterns, namely "surface" and "in-depth" learning approaches. This study aimed to investigate students' historical thinking ability using the Marton Phenomenography Analysis. Qualitative method was utilized with a phenomenography approach. The phenomenography approach was aimed to identify students' historical thinking ability as they experience, conceptualize, perceive, and understand various historical phenomena of social movements. The subjects were students who took part in Social History. Data were collected from examination, observation, interviews and document study. The results showed that students who have "surface" and "in-depth" learning patterns have different thinking patterns, perspectives, and perceptions. There is a significant difference as much as $12.11 \%$ in the historical thinking ability between both groups. The "in-depth" group has an advantage over the "surface" group in terms of understanding changes, comparing historical narratives, interpreting history, understanding historical interpretation, as well as constructing history. Both the "in-depth" and "surface" groups have a good ability in the aspect of knowledge on facts and how to search for historical sources. Finally, both groups have less ability to develop different thinking patterns, create questions from historical stories, and evaluate historical sources.
\end{abstract}

Keywords: in-depth learning, Marton phenomenography, historical thinking, history learning, surface

\section{ANALISIS FENOMENOGRAFI KEMAMPUAN HISTORICAL THINKING MAHASISWA DALAM MENGKAJI SEJARAH SOSIAL}

\begin{abstract}
Abstrak: Model analisis Fenomenografi Marton menarik diterapkan karena ciri penting pembelajaran ini didasarkan dua pola belajar secara akademik, yakni belajar dengan pendekatan "dangkal" (surface learning) dan pendekatan "belajar mendalam" (deep learning). Penelitian ini bertujuan untuk mengetahui bagaimana kemampuan historical thinking mahasiswa dengan menggunakan analisis Fenomenografi Marton. Pendekatan fenomenografi digunakan untuk mengidentifikasi kemampuan historical thinking mahasiswa saat mereka mengalami, mengonseptualisasikan, mempersepsi, dan memahami beragam fenomena sejarah gerakan sosial. Subjek penelitian adalah seluruh mahasiswa yang mengikuti mata kuliah Sejarah Sosial. Data dikumpulkan lewat tes, observasi, wawancara, dan studi dokumen. Hasil penelitian menunjukkan bahwa pada mahasiswa yang memiliki pola belajar "dangkal" dan "mendalam" memiliki pola pikir, cara pandang, dan persepsi yang berbeda. Kemampuan historical thinking pada kelompok mahasiswa tersebut memiliki perbedaan yang cukup signifikan, yaitu 12,11\%. Kelompok "mendalam" memiliki keunggulan dari kelompok "dangkal" dari aspek memahami perubahan, membandingkan kisah sejarah, menginterpreatasi sejarah, memahami penafsiran sejarah, serta mengkonstruksi sejarah. Kelompok "mendalam" dan "dangkal" sama-sama memiliki kemampuan yang baik dalam aspek pengetahuan tentang fakta dan cara mencari sumber sejarah serta juga sama-sama memiliki kemampuan yang kurang dari aspek membangun pola berpikir yang berbeda, membangun pertanyaan dari kisah sejarah, dan mengevaluasi sumber sejarah.
\end{abstract}

Kata Kunci: deep learning, fenomenografi Marton, historical thinking, pembelajaran sejarah, surface

\section{INTRODUCTION}

Historical thinking ability is one of the competencies required in learning history learning (Dickinson, Lee, \& Rogers, 1984; Fauzi, Santosa, \& Tarunasena, 2019; Wineburg, 1999). Developing students' critical thinking 
is the primary educational purpose in societies throughout the world (Larsson, 2017; Vivancos \& Ferrer, 2018). This ability required students to have learning ability, started from low levels such as knowledge regarding facts to a higher ability that is the ability to analyze sources and historical issues (Levstik \& Barton, 2011). The ideal purpose of learning history is not a little in the field shows there is a discrepancy with expectations. Learning history emphasizes more on the knowledge of facts alone, which is the lowest level in the ability of history so that the tendency to learn history is only memorizing it (Fauzi et al., 2019; Sharma, 2008).

Many factors caused the gap between what is expected and reality. Because in history learning there are several problems such as syllabus and the length of the content, conventional teaching methods, unsystematic use of teaching and learning materials, lack of interaction and feedback after an exam (Tok, 2016). Student learning outcomes can display in a competency form that can be measured. This competency explored through various learning methods. One of the competencies is historical thinking. To explore students' abilities in historical thinking, it can be done by using primary historical sources. Usually, this kind of learning is conducting by introducing students to historical sources that directly related to an event. This study uses the historical thinking concept from Wineburg (1999).

Historical thinking study can also be seen how competencies are demanded in the curriculum and how it implement in learning. Johanson (2015) conducted this sort of study in the curriculum in Norway. Johanson tried to examine how competencies description in the curriculum and the implementation in history learning (Johanson, 2015). Johanson's findings show that teaching conducted by teachers still uses traditional methods. The book and syllabus used regarding historical thinking were lack of concepts. Likewise, in the syllabus, tasks and evaluations did not measure a historical thinking ability. The research conducted by Johanson did not provide a clear picture of how the curriculum includes the historical thinking competency and what indicators are in historical thinking, as well as what learning models are suitable for the use of historical thinking. Even student characters are not visible.
Bernhard (2017) conducted a study in Norway by interviewing on how teachers' views explored the historical thinking ability in implementing learning. Bernhard's findings showed that when in the interview teachers stated that historical thinking is important, but in practice, it is rarely used. In carrying out learning the teachers, however, still, emphasize memorization. In the implementation of history learning, many teachers still use the ability of students to memorize (Bernhard, 2017). This research has not shown how interviews conducted and what reasons stated by history teachers' candidate did not carry out historical thinking as well as what factors that cause teacher candidates did not carry out historical thinking.

Vivancos \& Ferrer (2018) researched the prospective teachers' ability to understand and apply historical thinking ability. Prospective teachers read historical texts or narratives written by students to analyze them as required by historical thinking. The findings indicate that prospective teachers had minimum knowledge regarding historical thinking. One of the factors is because the teacher depends too much on the textbook. This study has not explained how teachers apply learning to students in understanding historical thinking and how the relationship between the use of textbooks with lack of knowledge regarding historical thinking (Vivancos \& Ferrer, 2018).

From previous researches, it has not seen how to explore historical thinking using the Marton Phenomenology Method. A study examines students' historical thinking abilities using the Marton Phenomenography Analysis. Phenomenography is a method in research, which tries to study the experience of a phenomenon by exploring information (Yates, Partridge, \& Bruce, 2012). Phenomenography originally developed by Professor Ference Marton and his colleagues at the University of Gothenburg in their study of learning. It later became widely used for learning and teaching in Australia, Hong Kong, Sweden, and the United Kingdom (Lam, 2019).

Phenomenography aims to describe, analysis, and understanding experiences (Marton, Cheun, \& Chan, 2019; Marton \& Pong, 2005; Stolz, 2020). Phenomenographic theory, in a promising way, can apply to understand 
concrete expressions of critical thinking and designing teaching to develop students' critical thinking (Larsson, 2017). Phenomenography seek to reveal various ways people experience the same phenomenon in the same situation. The object of research is thus qualitatively different, where people aware of the world, and how they experience various phenomena and situations around them, in which description categories and outcome space play an important role in describing how people experiencing reality (Ojo, Booth, \& Woollacott, 2019).

According to Ference Marton's theory, phenomenography as a learning pattern divided into two academically learning pattern, namely a "surface" and an "in-depth" learning approach (Biggs \& Tang, 2003; Marton \& Pong, 2005). In activities such as reading books, textbooks, and articles, some students were read subtopic by subtopic subsequently, without trying to find the main theme and its relevance to another essential concept. It called a surface learning approach. And there were students who tried not only to remember concept or key definition in each subtopic but they also tried to find the basic topics and the link between subtopics in articles with other important concepts. It called an indept learning approach (Marton, 2009; Marton et al., 2019; Marton \& Pong, 2005).

This study aimed to describe how to experience and understand a phenomenon, in this case, teaching and learning of social history phenomenon. This article will analyze how to explore students' historical thinking ability by using the Marton Phenomenology learning pattern. This study conducted because the previous studies did not measure two groups of students that learn "surface" and "in-depth" in historical thinking ability. Phenomenography is interested in investigating people's conceptions regarding the world or their experiences of learning from the second-order perspective (Marton, 2009; Stolz, 2020).

\section{METHODS}

\section{Approach}

The phenomenographic approach uses qualitative methods to obtain data for analysis (Larsson, 2017). For the initial stage, the implementation of phenomenography learning must determine a class group that studies "surface" and "in-depth" learning. Phenomenography researcher aimed to categorize their subject descriptions, and these categories, in turn, become the basis of phenomenographic research (Carlsson, Fülüp, \& Marton, 2001; Stolz, 2020). Phenomenography is commonly used to study various aspects of teaching and learning in higher education (Ojo et al., 2019).

\section{Subject}

The sample used is the total sample. It means that either population and sample, are the same number, namely the students of History Education at a state university in Bandung which take part in Social History subject as many as 80 people (two classes). Class A consists of 36 students, and Class B consists of 44 students. With the average GPA was: above $3.51(20 \%)$, 3.00-3.50 (67\%), and below 3.00 (13\%).

\section{Instrument and Data Collection Techniques}

This study used observation, interviews, exams, and document study as data collection instrument. The written exam is used to measure students' historical thinking abilities. The exam is conducted at the second meeting (multiple choices) and the tenth meeting (essay questions). The exam questions consist of essay questions (maximum score is 50) and multiple choices (50 questions with a maximal score is 50 ). The exam designed to measure the historical thinking ability based on indicators from Wineburg (1999), namely: knowledge of facts, how to search historical sources, different patterns of thinking, distinguishing past and present, understanding change, constructing questions from historical stories, evaluating history sources, comparing historical stories, interpreting history, constructing history, understanding the concept of cause and effect, and understanding the interpretation of history.

The multiple-choice questions asked regarding Indonesia's history material in general. The essay exam was in the form of social movement discourse events, which then to be asked to students to identify these events from the historical thinking aspects according to Sam Wineburg. Based on the students' answers, the researcher then identifies the historical thinking ability using the developed indicators. Based on indicators then developed assessment 
instruments and rubrics that show aspects of historical thinking abilities. The results from student answers identified using the reference rubric then the results was the percentage of the score obtained towards the overall score (the total of all aspects that should appear).

After the exam conducted, students grouped into "surface" and "in-depth" study groups. The standard of division showed in Table 1.

Table 1. Exam Result and Student Group Division

\begin{tabular}{lccc}
\hline \multirow{2}{*}{$\begin{array}{l}\text { Group } \\
\text { Characteristic }\end{array}$} & Essay & $\begin{array}{c}\text { Multiple } \\
\text { Choice }\end{array}$ & \\
\cline { 2 - 3 } Total Student \\
\hline Surface learning & $0-70$ & $0-70$ & 48 persons (60\%) \\
In-depth learning & $71-100$ & $71-100$ & 32 persons (40\%) \\
\hline
\end{tabular}

After being grouped, the exam results are personally analyzed based on the historical thinking indicators. Each indicator calculated as the percentage of students who answered correctly both from the surface and in-depth study groups. The result of the average score of the essay exam and the multiple-choice can be seen in Table 2.

Observations were conducted during the learning process. The question and answer, presentations, and group discussions process carefully observed. The various opinions and perceptions of the students recorded. These acts conducted because phenomenography concerned with expressing levels of individual and collective variation by focusing on the way certain people and groups or populations understand certain realities and phenomenography works to describe variations in qualitatively different ways of experiencing a phenomenon (Linder \& Marshall, 2003; Stolz, 2020). Phenomenography uses observations of teaching activities to identify qualitatively different ways of observing learning objects (Lam, 2019). The "surface" and "in-depth" study groups were observed particularly on how they argued, debated, presented, discussed, asked questions, and answered various socialhistorical events.

Besides exams and observations during the study, students were interviewed for their understanding regarding social movement concepts and confirm their perceptions that emerged in the learning process. Through this technique, students experience towards phenomenon can be identified (Linder \& Marshall, 2003). Interviews conducted with structured questions and answers during the learning process (one semester). Each meeting, 8-10 students are being interviewed for their understanding of local historical material.

Documentation studies carried out by studying articles collected in social history subject during the year of 2019/2020 academic session at the Universitas Pendidikan Indonesia. Each student is given the assignment to make a scientific article about one of the social movements discussed in the semester learning plan. The students perspective were sorted from the article, separated from historians' quotes and opinions. In addition, student narratives that combine various historians' perspective also used as research data.

\section{Data Analysis}

In examining learning outcomes, phenomenographic investigations are more focused on examining what is understood or learned by learners regarding the social history material. Similar studies tried to identify the various ways of student's thinking about the particular content in the learning material. Data's triangulation resulted from observations, interviews, and documentary studies used to complete an exam result's data regarding students' perceptions of local historical material. Each student performed their perception of the local history material by comparing various data from exam results, observations, interviews, and documentary studies.

\section{FINDINGS AND DISCUSSION Findings}

\section{Exam's Result of "Surface" and "In-Depth" Learning Group Ability}

Phenomenography research on students' interpretation of social history's material forming students that categorized into two types, surface and in-depth learners. The Table 2 is the results of their essay exams based on the categories of historical thinking skills. 
Table 2. Historical Thinking Ability of Surface Study and 'In-depth" Group

\begin{tabular}{lcc}
\hline \multirow{2}{*}{ Dimension } & \multicolumn{2}{c}{ Average score } \\
\cline { 2 - 3 } & Surface Study & In-depth Study \\
\hline Knowledge regarding fact & $75 \%$ & $90 \%$ \\
Way in finding a historical source & $70 \%$ & $85 \%$ \\
Different thinking pattern & $45 \%$ & $50 \%$ \\
Differentiating past and present & $63 \%$ & $76 \%$ \\
Understanding changes & $54 \%$ & $75 \%$ \\
Designing inquiry from history & $54 \%$ & $52 \%$ \\
Evaluating historical source & $47 \%$ & $47 \%$ \\
Comparing historical story & $53 \%$ & $60 \%$ \\
Interpreting history & $46 \%$ & $75 \%$ \\
Understanding history interpretation & $45 \%$ & $75 \%$ \\
Constructing history & $45 \%$ & $74 \%$ \\
Understanding causalities concept & $65 \%$ & $78 \%$ \\
\hline \multicolumn{1}{c}{ Average } & $55.17 \%$ & $69.75 \%$ \\
\hline
\end{tabular}

From the Table 2 can be described as follow. (1) Historical thinking ability in "surface" student group learning patterns there are as much as 7 indicators with the ability above $50 \%$. An indicator that under $50 \%$ is 4 . The average historical thinking ability in the group of students with low learning patterns is $55.17 \%$. (2) From these data, it concluded that students can identify various facts about social movements and can easily make the classification of historical sources based on sources from abroad and within the country. (3) Historical thinking ability in a group of students with "in-dept" learning patterns, there are 11 indicators with the ability above $50 \%$. An indicator under $50 \%$ is 1. (4) Historical thinking ability in a group of students with "in-dept" learning patterns, there are 11 indicators with the ability above $50 \%$. An indicator under $50 \%$ is 1 .

\section{Student's Perception Regarding Social History Material}

Phenomenography examines how learners perceive and understand the academic world they experience. For this reason, students observed when conducting academic activities. During four months of observation, data on students' perceptions regarding social history collected, while they were discussing, questioning and answering with lecturers, including during presentations. The observation focus is on how students interpret historical events they learn. The learning process can be more effective if educators understand the way students see the learning object.

Phenomenography research, which has a strong focus on student's perspective concerning a phenomenon. The theme of the material that discussed in the class includes:

1. Feminism movement in the United States in the 19-20 century.

2. Sukamanah Resistance (K. H. Zaenal Mustofa's confrontation with Japanese authorities in 1944).

3. The dynamics of social movements in the old order (student movement in 1966).

4. The Samin movement against the Dutch colonial government (1907-1930).

5. The role of the NAWSA (national American women suffrage association) organization in the prosecution of women's suffrage in the United States (1890-1920).

Phenomena can be experienced by students in different ways, depending on situation aspect that distinguished which brought to the student's focus awareness, and which certain aspect that remains in the thematic field. The following are their perceptions about Social Movement theme in Tasikmalaya during the Japanese occupation.

The results of phenomenography study are several description categories that reflect the various ways students see the object of learning. The most important thing for phenomenography is to uncover the original nature of the learning object as seen by students (Lam, 2019). 
Table 3. Student's Perception Regarding KH. Zaenal Mustofa Social Movement

\begin{tabular}{l} 
No. Student's Perception Regarding KH. Zaenal Mustofa Social Movement during the \\
Japanese Occupation \\
\hline 1. A policy that imposes Japanese traditions on Indonesian society. \\
2. The Cimerah Sukamanah Pesantren social proexam movement generates the spirit of Ulama \\
resistance in Indramayu. Not afraid of the Santri massacre and the arrest of its ulama. It can \\
be understood if in the rural areas of Indramayu, it will be easy to elevate the resistance spirit. \\
3. The role of the Kiai kampung during the Japanese occupation had a significant role as a bridge \\
to carry out political communication between the ruling government and the people. \\
4. Japan could localize the rebellion with the help of Indonesian accomplices. \\
5. Japan has brought into conflict tactic. Seeing what came to attack was Indonesia people, Zaenal \\
Mustofa ordered his students not to put up a fight before the enemy entered the fight circle. \\
6. That's why he was proficient in Arabic and has a very broad religious knowledge. Through the \\
pilgrimage, he became acquainted with leading scholars in Mecca and Medina. \\
7. Then the social movements based on the type of change was including conservative movements \\
that longing to maintain norms, values and etc. \\
8. KH. Zainal Mustofa also led a social movement carried out by the Japanese, where the \\
movement was not a movement demanding the seizure of rice by Japanese farmers, but a \\
political resistance movement. \\
The impact of the Japanese army arrival in Sukamanah village, made the surrounding community \\
suffer losses in the economic field and in terms of human resources, the community was greatly \\
disadvantaged. \\
10. The Sukamanah resistance movement pattern contained elements of religious totality that \\
possessed by the Santri and supported by the spirit of Jihad fi sabilillah in destroying pagan \\
rulers. \\
11. The emphasis on dissatisfaction factors corresponds to disunity theory; resources and \\
opportunities match with the social movements view as political activities in other ways, and \\
the construction of meaning and the formation of identity are allied concepts (Sukamanah \\
Movement).
\end{tabular}

The Table 3 showed students' ability to think historical as follows.

(1) A surface students' type, in various opinions, questions, and discussions only dwell on historical facts. They talked about many historical background facts, events, and social movements impact in Tasikmalaya in 1944, but there was no effort to express personal ideas about facts or evaluate them. They also did not appear to evaluate the reference sources they use. This evident from their view of the Social Movement in Tasikmalaya which arose because Japan forced its tradition into the Indonesian Muslim community. Students still trapped in the general narrative that causes the emergence of the $\mathrm{KH}$ movement. Zaenal Mustofa, namely religious factors (Seikirei tradition) and economic pressures without trying to see other factors. However, students have also tried to put forward the causal relationship of the social movement in Tasikmalaya 1944, one of which was to explain the social movement against Japan in Indramayu caused by social movement in Tasikmalaya.

(2) Students with "in-depth" learning category, tried to explain social movements in Tasikmalaya from concept and theory, for an example concept study of "Kiai kampung", "pesantren" and their role in the social life of Indonesian society during the Japanese occupation. They did not trap in fabricating facts, but try to explain the social structure that causes the resistance to emerge. Besides, students also examine the characteristic's factors against the KH. Zaenal Mustofa in both the Dutch and Japanese periods and identified Japanese tactics in quelling $\mathrm{KH}$. Zaenal Mustofa by localizing the conflict and tactics. By doing so, a conflict would not spread so that it would be difficult for Japan to control. In-depth students try to relate theory to the reality of resistance. They explained the relation of religion, economic pressure as a trigger factor for the movement by strengthening the identity politics that became the basis of resistance. 
Table 4. Student's Perception Regarding Social Movement in USA in 19-10 Century

\begin{tabular}{cl}
\hline No. Student's Perception Regarding Social Movement in USA in 19-10 Century \\
\hline 1. American women tried to gain their suffrage and equality with men. They want women to get \\
a higher education, join in the reform movement, and get involved in politics \\
2. In reality, The Declaration of Independence that emerge from the United States of America or \\
the concept of the Bill of Right is only a concept without being implemented properly \\
3. At its early history, American women have no right to make decisions in the household. All \\
decisions in the hands of men, both regarding the family, property rights, and children. And \\
women even did not have the right to determine their fate. But over time, things have changed. \\
Women who attend school and work beginning to appear, even though their presence has not \\
yet been fully accepted by the community.
\end{tabular}

4. In the social field, this feminism movement has an impact on women to obtain their civil rights in society includes in education. Unfortunately, developments in politics are not as fast as developments in education.

5. The impact of the feminism movement in the political sphere was that the United States government passed many laws on women. Women given the right to speak, the opportunity to join US political parties and work in the government sector includes becoming a minister.

6. After the struggle carried out by Malcolm X, a positive impact began to be felt for the socialpolitical life of colour people of the United States. The standard of living of colour people began to increase to become more prosperous, colour children began to feel an equitable education and able to enter public schools.

7. A breakthrough made by women has never subsided even created many signs of progress. Although there were dark sides to women such as lesbianism and liberalism, the most important is the radiating side that makes a useful and happy impact for both the community and their families.

8. The women deserve a vote because they are patriots, caregivers, and mothers. Women's expertise in defending their home and family will improve politics and society.

9. At that time, the society's structure that formed in the United States applied patriarchal culture. This patriarchate is a term that refers to a power relationship in which the interests of women considered to be inferior to men.

Table 4 shows student's historical thinking ability as follows.

(1) "Surface" type students, analyzing social movements in the 19-20 century US, triggered by racism, liberalism and feminism. Their opinions were no different from the narratives of the sources and references they read. It showcased from their opinion about the feminism movement in the US that emerged as an efforts to obtain equality with men in terms of suffrage, higher education, and involvement in politics.

(2) An "in-depth" student type, tried to assess historical reality that they put forward, one of which that saw the Declaration of Independence and the Bill of Right, just merely a concept without being applied well in the USA. Another example of assessment was on the impact of racism and feminism in the USA solely in the field of Education, but it is difficult to realize in the political field so they assess the US even though it said to be a democratic pioneer country has not recognized gender and racial equality. Feminism considered had dark sides such as lesbianism and liberalism and women experienced boredom with domestic work. As in social movements in Tasikmalaya in 1944, students used concepts and theories in studying social movements in the US, one of which was the use of the patriarchal's concept in analyzing the feminism movement and racism in the US. 
Table 5. Student's Perception Regarding Samin Movement

\begin{tabular}{l} 
No. Student's Perception Regarding Samin Movement During the Dutch Colonial Period \\
\hline 1. Samin taught his member to surrender, semeleh, to be patient, narimo ing pandum like silent \\
lake water. \\
2. In his political teachings, Samin Surosentiko invited his followers to oppose the Dutch Colony \\
Government. This attitude manifested through rejection of taxes payment, rejection to improve \\
the road, rejection to guard at night (patrol) and rejection on forced labour/ compulsory. \\
The resistance of the Samin people against the colonial government was not executed in a \\
physical way, but by refused to contribute to the village granary and to keep their livestock \\
in public cages. They were still willing to pay taxes but not as obligations but as voluntary \\
donations. \\
But other things distinguish it, that usually this kind of social movement is only short-lived, \\
but Samin Movement still exists today. This existence is none other than because there is still \\
a Samin community that still adheres to Saminism teaching. \\
Poverty was not anxiety source. But depress because they have to comply with the injustice \\
that is difficult for them to deal. Farmers suffer because they were unable to avoid and fulfil \\
government obligations. Thus the villager's suffering because they did not allow to gather \\
forest products and the heavy tax burden, was the cause of emergence. \\
Neil Smelser in structural strain theory explains the emergence of the mass movement into five \\
causes. First, structural conditions such as social, economic and political conditions. Second, \\
the emerging of social movements is driven and caused by tensions within the community \\
itself, including various patterns of social conflict or where the community failed to meet the \\
expectations of its members. Third, the students' confidence to demonstrate. Fourth, leaders \\
start, suggest, and direct activity. Fifth, the implementation of social control carried out by the \\
leader of the movement, the strength of the security forces, changes in government policy to \\
other social controls that considered pressure on the people.
\end{tabular}

Table 5 shows student's historical thinking ability as follows.

(1) Surface type students, analyzed the Samin Movement from the causes, Samin against the Dutch, and the movement's impact. They described facts relating to these three aspects. They elaborated various social, economic, political, and religious factors which caused the movement to emerge. However, students did not try to analyze the dominant factors or at least assess or integrate the various opinions of historians regarding the Samin's movement.

(2) An 'in-depth'students, tried debate whether the Samin Movement was a Millennialism or Messianic Movement. They explore these concepts and conclude the movement. They also described the uniqueness of the movement because this social movement was only shortlived, while the Samin movement still exists today. Their existence is because there still a Samin community who adheres to Samin's teaching. Besides, the students were skilful in analyzing the movement by using Neil Smelser's theory in structural strain.
Table 6 shows students historical thinking ability as follows.

(1) A surface's type of student analyzed social, political, and economic factors that fostered the 1966 student movement in Indonesia, the process of massive demonstrations, and their impact. They tend to assess the Student Movement as their initiative, without waiting for orders from anyone.

(2) An 'in-depth' students analyzed the military role in the 1966 student movement, including military and student relations to overthrow Sukarno's power. They considered that the 1966 student movement did not appear spontaneously yet strongly related by the struggle of the political elites of the Old Order era. The movement carried out by KAMI that well organized due to many supports from the military and political parties including mass organizations. In addition, students were good in explaining the unique characteristics of the movement and the focus of the 1966 student social movement. 
Table 6. Student's Perception Regarding Social Movement in Indonesia in 1966

\begin{tabular}{cl}
\hline No. Student's Perception Regarding Social Movement in Indonesia in 1966 \\
\hline 1. The focus of this social movements includes the rights of the people. \\
2. Students as middle class and intellectual feel the urgency of the movement targeted towards \\
people condition and the government policy that worsened as it happened in 1966. \\
3. The students as intellectual began to see how people condition declined as well as worsened \\
government policy. They began to proexam against the Sukarno government. \\
The students carried out the movement without orders from anyone, purely their initiative \\
and spearheaded the proexam movement against Sukarno. In its development around October \\
1966 students who anti-PKI formed an organization KAMI (Indonesian Student Action Unit) \\
which supported and protected by the army. \\
This conflict occurred due to the government and people's disparity. So thus, there was a \\
student movement in 1966 as a conveyor and intermediary of people's aspirations. \\
The rise of the 1966 student movement motivated by an economic and political crisis in \\
Indonesia. The 1966 student movement was pioneered by KAMI. KAMI (Indonesian Student \\
Action Units) were present in every major city of Indonesia that brings together all student \\
demonstrations. \\
Therefore the purpose of the student movement in 1966 was not merely to demand power \\
and political power. But rather to defend themselves from government policies that were \\
considered unfavourable and focused more on the interests of people's lives. \\
When related to social movement concept, the 1966 student movement called as a new \\
social movement. This new social movement is more focused on non-material goals. Usually \\
emphasizes changes in lifestyle and culture rather than encouraging specific changes in public \\
policy or economic change.
\end{tabular}

\section{Discussion}

\section{The Pattern of "Surface" and "In-dept" Study}

In the phenomenography approach, it is an axiom that everyone has a different way of understanding, seeing or experiencing the phenomena they encounter (Marton, Watkins, \& Tang, 1997). From various observational findings, interviews, document studies during the learning process, several students' characteristic with "surface" learning patterns found, as follows.

1. Students had knowledge regarding facts and how to find a good history source. Wineburg (1999) considers that remembering names, dates and events is much easier than changing the basic structure of way of thinking that use to understand the meaning of the past.

2. Students could identify various facts about social movements and able to classify historical sources easily.

3. Students did not perform higher historical thinking ability, namely, to interpret history with a different perspective, to understand historical interpretations and assess historians' interpretations, construct history and understanding change.
4. Students only dwell on historical facts both the background, the course of events, and the impact of these social movements.

5. Students analyzed various social, economic, political, and religious factors that cause the movement, yet they neglected dominant factors, or at least assess or integrate historian's opinions.

6. Students unfeasible to assess the reference sources they used.

7. Students have tried to express the causal relationship between social movements.

The data shows that students who fall into the category of "surface" learning pattern are $60 \%$. It showed that most students learned history from the knowledge of facts. They have difficulty in constructing facts and evaluating historical sources.

Meanwhile, students with "indepth" learning pattern have the following characteristics:

1. Students have good ability regarding knowledge of facts and how to search for historical sources.

2. Students were able to construct history and understand aspects of change, compare 
historical stories, interpret history, and understand various history interpretations. The ability to interpret history is important for students. Historical stories are powerful cultural force because it could impressively present historical interpretations and directly impact on students' historical thinking (Levstik \& Barton, 2011).

3. Students could explain social movements from concept and theory by relating theory with resistance's reality. According to Wineburg (1999), understanding history is "seeing through the eyes of people who lived at the past and history should teach us what we cannot see, to introduce us to faded vision since we were born.

4. Students did not trap in fabricating facts, but try to explain the social structure that causes resistance.

5. Students assessed the historical reality that they put forward and describe the uniqueness of the movement.

During class, lecturers apply more on active learning methods such as discussion activities, problem-based learning, games, thematic approaches, etc. The data showed correlated to Narmaditya, Wulandari, \& Sakarji (2018) that the Application of Problem-Based Learning also encourages students to have critical thinking skills in various activities such as asking questions, discussing problems, and making solutions. Although lecturer has tried to implement active learning, the majority of students are still in the "shallow" category (Narmaditya et al., 2018).

\section{Historical Thinking Ability}

By having historical thinking ability, students will be able to think chronologically, understand changes in time, analyze historical literature, understand how to look for historical sources, understand the concept of cause and effect in history, and understand historical interpretations (Wineburg, 1999). The historical thinking ability towards students who have "surface" learning patterns and "in-depth" learning, showed a significant difference that is $12.11 \%$. An in-depth group had strength over the surface group in terms of understanding change, comparing historical narratives, interpreting history, understanding historical interpretations, and constructing history.
Table 2 also showed "surface" learners where they did not perform higher historical thinking ability, namely to interpret history with a different perspective, understanding historical interpretations and assess historian's interpretations, construct history and understanding changes. These proven from their opinions that appear during the class' process. Students' ability to evaluate historical evidence manifested in two ways, namely critical questions about historical evidence and the results of their analysis of historical evidence. These two rarely found in "surface" groups.

Both in-depth and surface groups had good ability in terms of knowledge of facts and how to look for historical sources. From table 2 showed students' ability with a surface category indicates knowledge of facts and how to find a good source of history. It also showcased during class, discussions, questions and answers with a lecturer, as well as from their papers. The historical thinking basic ability, namely knowledge of facts, has a high percentage in both groups. This shows that learning history started from the knowledge of facts is significant to possess for those who will study history. Even though history is a humanities science, yet it still has preliminary requirements that must be experienced by knowledge of facts. These in accordance with social history implementation where students usually invited to find out about facts. Knowledge of facts is the beginning of learning about history (Lloyd, 1989).

The interesting thing about the data, both in "surface" learning and "in-depth" learning pattern, appeared data with a similar number with a small percentage that is $47 \%$ in several aspects. An in-depth and surface groups both have less ability to develop different thinking patterns, constructing questions from historical stories, and evaluating historical sources aspect. This ability requires a high thinking ability. In fact, Wineburg (1999) concludes that to be able to think history, means that it requires thinking in ways that are contrary to everyday thinking. Wineburg agreed with Ginzburg's argument that the purpose of learning history is to teach what we cannot see.

In history, the highest truth is the interpretation's result (McCullagh, 2002). When someone makes a historical interpretation required the ability to evaluate historical sources 
based on concepts or theories from social science or other sciences (Lloyd, 1989). Students who study social history could predict had less understanding regarding concepts or theories that will be used as tools in analyzing historical sources. The data showed the relevance of Vivancos \& Ferrer (2018) that prospective teachers have limited ability regarding high historical thinking. This requires more rigorous training for students to have good historical thinking as Wineburg (1999) mentioned that the historical thinking process is not a natural process and not something that suddenly arises from the psychology development.

Indicators of historical thinking ability towards students who had "surface" learning patterns, the majority were under $50 \%$ compared with an "in-depth" student's learning patterns. In "surface" learning pattern the percentage that below $50 \%$ are 5 indicators, namely, different thinking patterns in evaluating historical sources, interpreting history, understanding historical interpretation, as well as to construct history.

The five indicators require students to have abstract thinking concepts which then applied in historical methodology or historical research as a form of student learning outcomes. Weak indicators on "surface" thinking student because students required to combine concepts with applications. For example, the ability to evaluate historical sources is the ability for students that requires to criticize or validate historical sources as part of the historical research step.

Students must be able to differentiate whether the source is authentic or not, whether the source is primary or secondary, whether the historical interview given by someone is a lie or truth and so on. Even before evaluating historical sources, students must know what characterizes something as historical sources, whether written, oral and object. The five indicators on "surface" thinking students strengthen Vivancos \& Ferrer (2018) argument that prospective history teachers have weaknesses in understanding historical thinking, due to many understandings regarding material through textbooks. Such material understanding tends to understand history only by memory.

The five indicators required a student's ability to have a high level of thinking that is not just knowledge of facts. There is three key ability required in the five indicators, namely construction, evaluation and interpretation. These three keywords are procedures that must be taken in historical research when a historian finds a source. In historical research, some steps are collecting sources, source selection, interpretation and historiography (Padmanabhan $\&$ Gafoor, 2011). The source selection step is the step of evaluating the source, which is true or false, which is genuine or fake. Interpretation and historiography are the steps to construct selected sources which then compile a historical or historiographic narrative (van Alphen \& van Nieuwenhuyse, 2019).

In carrying out the construction, a historian required to have an abstract imagination's ability. The abstract in question is to use theory in compiling historical sources into a narrative communicated to the public (Bernhard, 2017). This capability is, of course, necessary to be able to understand the historical methodology in depth. A "surface" learning pattern has a significant correlation to the indicators in historical thinking. This data, strengthened by Cheng's (2016) view that phenomenography demanded students on a higher ability that is awareness and self-reflection ability.

Students' understanding of phenomenography requires students to see phenomena in history that must be analyzed. A phenomenon can be studied by viewing at historical reality. Historical reality can be seen in the past context as well as in a contemporary context. For example, understanding an event as a phenomenon that may occur in the present. Such abilities as stated by Fauzi et al. (2019) that students can be trained in brain-based learning abilities (brain-based learning), a learning model that emphasizes much on the skills possessed by the brain. These skills can be developed in understanding the indicators that exist in historical thinking (Fauzi et al., 2019).

\section{CONCLUSION}

This study has shown significant differences in exploring students' historical thinking ability towards "surface" and "indept" learning pattern. These two groups were also strongly influenced by learning motivation. Those with high motivation in learning then will carry out an "in-depth" learning attitude and vice versa. Motivation strongly influenced by various factors, namely internal factor developed from 
students and external factor that is outside.

There are three relationship variations of "surface" and "in-depth" students type. And there is similar historical thinking ability between "surface" and "in-depth"s type as well as several the historical thinking abilities that the "in-depth" group superior to the "surface" type. The result found that the historical's thinking abilities wether the "in-depth" and "surface" groups were both less mastered. An "in-depth" have strength over "surface" group in terms of understanding changes, comparing historical stories, interpreting history, understanding historical interpretations, and constructing history. An "in-depth" and "surface" groups had a good ability in knowledge about facts and how to search for historical sources. "In-depth" and "surface" groups both have lack ability in regards to develop different thinking patterns, design questions from historical's story, and evaluating historical sources.

\section{ACKNOWLEDGEMENT}

I would like to thank the Lembaga Penelitian dan Pengabdian Masyarakat Universitas Pendidikan Indonesia for providing funding in this research.

\section{REFERENCE}

Bernhard, R. (2017). Are historical thinking skills important to history teachers? Some findings from a qualitative interview study in Austria. History Education Research Journal, 14(2), 29-39. https:// doi.org/10.18546/HERJ.14.2.03.

Biggs, J., \& Tang, C. (2003). Teaching for quality learning at university. Maidenhead, England: SRHE. OUP.

Carlsson, M. A., Fülüp, M., \& Marton, F. (2001). Peeling the onion: Student teachers' of literary understanding. Scandinavian Journal of Educational Research, 45(1), 5-18. https://doi. org/10.1080/00313830020023366.

Cheng, E. W. L. (2016). Learning through the Variation Theory: A case study. International Journal of Teaching and Learning in Higher Education, 28(2), 283-292. http://www.isetl.org/ijtlhe/.
Dickinson, A. K., Lee, P. J., \& Rogers, P. J. (1984). Learning history. Lincoln, UK: Heinemann Educational Publishers.

Fauzi, W. I., Santosa, A. B., \& Tarunasena, T. (2019). Optimizing the use of history textbook through brain-based learning. Paramita: Historical Studies Journal, 29(2), 139-156. https://doi.org/10.15294/ paramita.v29i2.15729.

Johanson, L. B. (2015). The Norwegian curriculum in history and historical thinking: A case study of three lower secondary schools. Acta Didactica Norge, 9(1), 5-24. https://doi.org/10.5617/ adno.1301.

Lam, H. C. (2019). The phenomenography tradition in the study of classroom teaching. International Journal of Research and Method in Education, 42(5), 513-524. https://doi.org/10.1080/174372 7X.2018.1518417.

Larsson, K. (2017). Understanding and teaching critical thinking - A new approach. International Journal of Educational Research, 84(December 2016), 32-42. https://doi.org/10.1016/j.ijer.2017.05.004.

Levstik, L. S., \& Barton, K. C. (2011). Doing history: Investigating with children in elementary and middle schools. New York, NY: Routledge.

Linder, C., \& Marshall, D. (2003). Reflection and phenomenography: Towards theoretical and educational development possibilities. Learning and Instruction, 13(3), 271-284. https://doi.org/10.1016/ S0959-4752(02)00002-6.

Lloyd, C. (1989). Realism, structurism, and history. Theory and Society, 18(4), 451-494. https://doi.org/10.1007/ BF00136435.

Marton, F., \& Säljö, R. (2005). Approaches to learning. In F. Marton, D. Hounsell, \& N. J. Entewistle (Eds.). The experience of learning: Implications for teaching and studying in higher education. California, CA: Scottish Academic Press, pp. 106- 
125.

Marton, F. (2009). Beyond learning as changing participation. Scandinavian Journal of Educational Research, 53(2), 211-215. https://doi. org/10.1080/00313830902757675.

Marton, F., Cheung, W. M., \& Chan, S. W. Y. (2019). The object of learning in action research and learning study. Educational Action Research, 27(4), 481-495. https:// doi.org/10.1080/09650792.2018.148987 3.

Marton, F., \& Pong, W. Y. (2005). On the unit of description in phenomenography. Higher Education Research and Development, 24(4), 335-348. https://doi. org/10.1080/07294360500284706.

Marton, F., Watkins, D., \& Tang, C. (1997). Discontinuities and continuities in the experience of learning: An interview study of high-school students in Hong Kong. Learning and Instruction, 7(1), 21-48. https://doi.org/10.1016/S09594752(96)00009-6.

McCullagh, C. B. (2002). The truth of history. London: Routledge.

Narmaditya, B. S., Wulandari, D., \& Sakarji, S. R. B. (2018). Does problem-based learning improve critical thinking skill? Cakrawala Pendidikan, 37(3), 378-388. https://doi.org/10.21831/cp.v38i3.21548.

Ojo, E., Booth, S., \& Woollacott, L. (2019). Faculty's conceptions of teaching introductory economics in higher education: A phenomenographic study in a South African context. International Review of Economics Education, 30, 1-11. https://doi.org/10.1016/j. iree.2018.05.001.
Padmanabhan, N., \& Gafoor, P. A. (2011). Methodology of history. India: Calicut University.

Sharma, S. K. (2008). Teaching of history. New Delhi: lotus Press.

Stolz, S. A. (2020). Phenomenology and phenomenography in educational research: A critique. Educational Philosophy and Theory, O(0), 1-20. https://doi.org/10.10 80/00131857.2020.1724088.

Tok, B. R. (2016). Learning problems in History subject among the Secondary School-Students of Papum-pare district of Arunachal Pradesh. IRA International Journal of Education and Multidisciplinary Studies, 5(2), 133-139. https://doi.org/10.21013/jems.v5.n2.p9.

Van Alphen, F., \& Van Nieuwenhuyse, K. (2019). Conceptualizing 'identity' in History Education Research. International Journal of Research on History Didactics, History Education, and Historical Culture, 40, 81-114.

Vivancos, A. E., \& Ferrer, L. A. (2018). What is historically significant? Historical thinking through the narratives of college students1. Educ. Pesqui, 44 São Paulo, 1-16. https://doi.org/10.1590/s16784634201709168641 .

Wineburg, S. (1999). Historical thinking and other unnatural acts. Phi Delta Kappan, 80(7), 488-499. http://www.jstor.org/ stable/2043949

Yates, C., Partridge, H., \& Bruce, C. (2012). Exploring information experiences through phenomenography. Library and Information Research, 36(112), 96-119. https://doi.org/10.29173/lirg496. 